\title{
CASTING THE LIGHT ON CINEMA - HOW LUMINANCE AND CONTRAST PATTERNS CREATE MEANING ${ }^{1}$
}

\author{
Anna Maszerowska \\ Universitat Autònoma de Barcelona (Spain) \\ Centre d'Accessibilitat i Intel-ligència Ambiental de Catalunya \\ anna_maszerowska@o2.pl
}

\begin{abstract}
The question of meaning creation has always been at the core of cross-disciplinary scholarly research. Considered from the cinematographic perspective, it inevitably evokes correlations with plot and dialogue. However, the conveyance of significance in films does not rely solely on the verbal channel, but also manifests itself in the visual layer, ranging from facial expressions, setting and locations, to directorial editing choices. Elevating the role of the how of film making, this article focuses on the influence of light and contrast patterns on the reading of cinema. In order to highlight their position in film text vocabulary and recognize their relevance in film translations and adaptations, this paper discusses the role of luminance patterns in active perception within motion pictures, explores their potential contribution to plot completion, and investigates the processes of filmic content hierarchization supported by light and contrast.
\end{abstract}

\section{Resumen}

La cuestión de la creación del sentido siempre ha sido recurrente en la investigación académica. Considerada desde la perspectiva cinematográfica, nos lleva automáticamente a pensar en la trama y los diálogos. Sin embargo, la transmisión del sentido de

1. This research is supported by the grant from the Spanish Ministry of Science and Innovation FFI2009-08027, Subtitling for the Deaf and Hard of Hearing and Audio Description: objective tests and future plans, and also by the Catalan Government funds 2009SGR700, and the European Project AD LAB: Audio Description. Lifelong Access for the Blind with reference no. 517992-LLP-1-2011-1-IT-ERASMUS-ECUE. 
las películas no se basa únicamente en su canal verbal, sino que también se manifiesta en su capa visual, comprendida en las expresiones faciales, la composición, la localización y la edición. Centrándose en el cómo, el artículo presta especial atención a la influencia de los patrones de luz y contraste en la lectura del cine. Con la intención de resaltar su rol en el lenguaje cinematográfico y su relevancia en traducciones y adaptaciones, la autora reflexionará sobre el papel de los patrones de luminiscencia en la percepción activa de filmes, su potencial contribución a la comprensión de la trama y los procesos de jerarquización contenidos en la luz y el contraste.

Keywords: Light. Contrast. Meaning formation. Film studies. Cinematic language.

Palabras clave: Luz. Contraste. Formación del sentido. Estudios fílmicos. Lenguaje fílmico.

Manuscript received on June 29, 2011; Definitely accepted on November 15, 2011. 


\section{Introduction}

According to Bordwell and Thompson (1990: 40), the essential features which contribute towards the enjoyment of a film are the emotional responses of the audience towards the image they are confronted with, their subjective evaluation of its aesthetic characteristics, and their recognition of the meaning that the relevant film carries. The latter is however still popularly considered to be limited to the cues revealed solely in dialogues, gestures, and plot sequences, whereas the successful and correct reading of all motion pictures strongly relies on the constant interplay of both the what and the how. The significance of any movie also lies in the unique and carefully structured camera movements, editing and soundtrack choices, and staging parameters. Whilst these components seem to have already received substantial attention within academia, light and contrast patterns, which will constitute the main focus of this paper, are given substantially less attention in the field of academic research and are still regarded by most as mere object illumination and shape revelation tools. According to Geuens, (2000: 151) the cinematographic irrelevance of light and contrast is often justified by their regular presence in our everyday lives, and their purposeful employment in films is frequently rationalized and consequently downplayed. However, it has been widely acknowledged that luminance patterns shape our perspective and influence our perception of the world and, indeed, of art. Even though, as Malkiewicz (1986: 1) puts it, physical objects and people do not normally undergo considerable changes as days or weeks go by, the mere sources of light and the environmental circumstances prevalent at a given moment in time do naturally modify the visual characteristics of the subject in question. Solso (1994: 45) claims that in this respect, the viewer's experience of any artwork does begin with the sensorial reception of the range of light signals that the relevant object reflects, but it then concludes with their composition into a meaningful and logical entity, which is finally interpreted accordingly by the viewer's mind. In this way, we create what the author likes to call "the final perception". Moreover, Bordwell and Thompson (1990: 133) argue that light has the unique ability to lead the eyes of the viewer on the screen and thus reveal to them the following 
sequences of the image, at the same time obscuring the irrelevant and elevating the critical. ${ }^{2}$ Monaco (2009: 218-19) adds to the debate by stating that luminance patterns help to "modify the meanings of form, line, and colour, and their intrinsic interests". Continuing along this line of thought, Millerson (1991: 10) invests this directorial tool with the ability to convince the audience, keep them engrossed in what is happening on the screen, and contribute to the impression of "depth, solidity, texture, <and> form" of the visual channel. This argument is also found in the discourse led by Geuens (2000: 164). He claims that lighting brings together the fictional characters and the viewer, thus functioning as a subtle (though powerful) link and leveller.

As can be inferred from the aforementioned studies, light and contrast assume a leading role in the meaning formation of a film narrative. This is why the successful understanding and proper appreciation of these elements will result in immediate positive outcomes both in terms of comprehensive film reading and also in many translation activities such as subtitling, dubbing, subtitling for the deaf and hard of hearing or audio description. In this respect, this paper also aims to elevate the role of luminance patterns in bridging the gap between directorial intentions and the viewer's final response. The article's main objective is to attempt to categorize the whole range of explicit and implicit meanings that viewers normally discern from the implemented luminance solutions, and to localize their position in the process of film reading. In order to amplify the concept of film meaning and interpretation, this article will carry out a thorough investigation of the existing lighting modalities and measure their potential in fulfilling the cinematographic purpose.

\section{Film meaning: composition, acquisition and organization}

With the exception of some hermetic and stylistically sophisticated movies, most films can be successfully understood by the average audience. However, owing to the social pressure that assumes the existence of a single interpretation of the director's message, as well as because of the lack of a universal tradition of extensive imagery consumption, the range of reading dimensions of a motion picture still seems to be limited. Ostaszewski (1999: 63) and Stafford (2007: $78 \&$ 81) claim that in this respect, any discussion concerning cinematic reality should begin by saying that films, much like words, have no meaning in themselves and therefore function as mere representations of relevant concepts. It is only in specific cultural and social contexts that

2. A claim supported by Nelmes (2003: 70) and Mital et al. (2011). 
they reveal their (intended) significance and are consequently brought to life. However, in the case of motion pictures, there is never only one interpretation. Every viewer, depending on their background, reads the relevant image differently, so it cannot be assumed that all members of the audience will report the same artistic experiences and understand the message of the film in the same way. One may neither anticipate nor faithfully predict each viewer's exact response. Nevertheless, it is through the audience's acquired ability to attribute significance to films, and their interaction with the visual stimuli, that the range of possible cinematic interpretations can experience constant and creative growth. As Solso (1994: 147) puts it, art is not only to be visually perceived, but first and foremost to be mentally processed, localized and positioned. Monaco (2009: 189) repeats this claim by considering cinema "an art and a medium of extensions and indexes", with a large proportion of the ultimate meaning coming from the constant interplay of, and the alternating between, the seen and unseen. This argument coincides with Stafford's (2007: 83) deliberations on film intertextuality - some motion pictures allude to meanings already seen in other productions which, when combined, give the full image of what the current material is about. Discarding therefore the concept of one correct film reading and adding to the processes of cinematographic artwork consumption the figure of an 'active viewer', this assumption gives way to the successful perception of motion pictures' metonymical and metaphorical dimensions. (Ostaszewski 1999: 63) In addition to what Bordwell and Thompson (1990: 40) refer to as "explicit meanings" (i.e. obvious conclusions to be drawn from the relevant image), the range of film reading modalities identified by said authors extends to:

- Referential cues - concepts based upon a viewer's background knowledge and their ability to recognize the relationships between respective film subjects, which manifest themselves vividly in von Trier's productions. Think for instance of Antichrist (2009), where a consciousness of the director's personal disposition (i.e. thinking outside the fictional frame) is vital for the viewer to be able to follow and understand the plot.

- Implicit meanings - at times ambiguous, vague messages to be read on the basis of inferential activities and deeper reflection. For instance, in the film Equilibrium (2002, Wimmer) the metaphor of human cynicism, hypocrisy, and moral destruction is carried between the lines, subtly suggested to the viewer in the guise of a fictional city called Libra. 
- Symptomatic meanings - figures by which the director intends to call on audience's set of moral values, thus creating a story with implications about the world and the times we live in. For example, the consequences of excessive perfectionism and preoccupation with appearances may lead to irreversible decay and psychological disturbances, as depicted in Black Swan (2010, Aronofsky).

The different categories of meaning mentioned above correspond to denotative and connotative planes identified by Orero (2012): on the one hand, an image is only what one perceives with one's own eyes and there is nothing more to it. On the other hand, apart from being simply a physical reflection of existing objects and shapes, some visual stimuli allude to or refer to more complex, contextually embedded and metaphorical issues, which, in order to be successfully recognized by the audience, require proper background knowledge and schema activation. (Sturken and Cartwright 2001: 19) According to Ostaszewski, this in turn is immediately reflected in the processes of film understanding and interpretation. While with the former there is a significant risk of reading a given piece of cinematographic art literally and thus discarding it as incoherent and illogical, the latter works on the assumption that the viewer will go beyond the obvious, operate on a more global scale, and put seemingly irrelevant pieces of information together so as to arrive at a meaningful conclusion. Since both activities are known to be mutually complementary, it is virtually impossible to tell them apart. As a matter of fact, in order to understand a given image, he asserts that one has to interpret it and vice versa. Since the composition of motion pictures is a logical process combining various interactive and mutually dependent codes, understanding and deciphering the cues of any film requires both active thinking and attentive form reading. Finally, he claims that the more elaborate the cognitive effort, the more visible the stylistic distinctiveness and specificity of the piece of art in question (1999: 73-74 and 102, 168). As Solso observes (1994: 96), the above mentioned argument has been broadly supported by gestalt psychologists, and was ultimately reflected in the notion of Prägnanz, as these scientists discovered a tendency for the human brain to look for carefully and regularly structured patterns and revealed a far-reaching though not easily definable discomfort with disturbed forms and shapes. This accounts for the way that many film directors resort to "bad" figures in order to allow their audience to develop their own, creative ideas and conclusions, and enjoy the whole spectrum of possible scene significances. However, as Ostaszewski (1999: 77) claims, this 'abstract thinking' can only be put into practice voluntarily. 
Obviously, not only will every viewer have different expectations as to what a given film represents, but they will also vary in their level of personal engagement and, consequently, in the spectrum of meaning they infer. On the other hand, advanced processing activities and broader visual competence guarantee the discovery of all possible contexts and levels of significance, since the missing links needed for successful form reading are often to be found in the language of such ambiguous tools as cinematographic conventions.

\section{Cinematographic conventions as a mode of conveying meaning}

The aspect of the how of shooting a film has long been elevated in literature discussing film studies. Its importance in the construction of film meaning was noted as early as 1975, when Chafe carried out his experiment broadly known as Pear Stories (Orero 2008). A group of American students were asked to provide a summary of a short film designed specifically for the purposes of the research in question. It turned out that instead of following a narrative approach and engaging in the plot, their initial commentaries related to the camera set-up, colours, and other visual techniques used in the clip, a conclusion of tremendous importance in terms of both media accessibility and the context of audiovisual translation. It shows that one cannot discard some aspects of film production as irrelevant or assume that the meaning to be conveyed must always be examined in isolation from the cinematographic conventions employed. Furthermore, this supports the idea that motion pictures are preliminarily perceived as collages of technological solutions to which viewers add their own logical interpretations, and activate more elaborate reasoning. This is not to say that the form is superior to the content, indeed quite the opposite; both form and content need to be seen as harmonious and mutually dependent dimensions aimed at the disclosure of all possible shades of significance and clues (Ostaszewski 1999: 64). Any technique employed by a particular artist potentially enriches the reception of the relevant material, providing it with a certain spirit and character. As Monaco (2009: 189) puts it, the ultimate power of cinema lies more in the way relevant images are presented than in what they actually show, and according to Bordwell and Thompson (1990: 41), "it is the form of the film that gives the familiar saying an unfamiliar weight". It is therefore only in a specifically determined context that the techniques employed acquire a deeper meaning and cease to be plain use of technology. However, following Fix and Morgner's claim (2005: 131), while watching a film we do not individually analyze every single cinematic technique, but instead automatically embrace the overall effect, possibly without even being aware of their purposeful interplay. Many directors of 
photography stress this paradox when talking about their work, at times employing elaborate solutions in order to support the final feeling of the movie, even though the audience remains indifferent. They often downplay these effects, claiming that they did not contribute in any relevant way to the development of the plot (Geuens 2000: 151). This is partly because directors use a whole battery of specific tools and techniques which subtly lead the viewer's eyes on the screen with the intention of revealing meaning to us. Mital et al. (2011) claim that such intentional capturing of the attention of the viewer ensues by means of external (exogenous) stimuli, such as luminance and color.

\section{Light and contrast techniques - meaningful language without words}

When analyzing the role of luminance patterns in cinema, one must depart from the very basic assumption that it is light that brings all objects to life by making them visible to human eye and providing them with a certain shape, tangibility, and temperature. Whilst, as Revault acknowledges (2003: 9), this process occurs more or less arbitrarily and reveals a significant lack of hierarchical structure, the employment of luminance patterns in cinema is subject to a strict and logical strategy, specifically aimed at conveying certain meaning and significance. This argument is reflected in the words of one of the greatest directors in the history of cinema, Fellini, who once acknowledged that:

Light is the very substance of a film. In film [...] light is ideology, feeling, color, tone, profundity, atmosphere, storytelling. Light is what adds, cancels out, reduces, exalts, enriches, creates nuances, underlines, alludes to; it makes the fantastic and the dream believable and acceptable or, on the other hand, makes reality fantasy and turns everyday drabness into mirage; it adds transparency, suggests tensions and vibrations. Light $[\ldots]$ creates expression where none exists, endows dullness with intelligence, makes the insipid seductive. Light outlines the elegance of the body, glorifies a countryside which may be nothing by itself, gives a background magic. [...] Whatever is made on film lives by means of light. [...] Films are written in light, their style expressed by means of light. (Fellini \& Grazzini 1988: 154-157)

Over the course of time, patterns of light and contrast have begun to enjoy increased importance within the cinematographic environment, with the heaviest burden of meaning continuously being shifted from mere setting illumination to emotion and plot expression (Gutiérrez San Miguel 2002: 101). The catalogue of further possible interpretations of luminance language, albeit far from complete, is as follows: 
a) Editing tools: content classification and hierarchy

- According to Anderson et al. (2005: 154-155), lighting patterns influence the distribution, frequency, and intensity of eye fixations in the viewer. In a relatively unanimous setting, the objects highlighted by means of a purposeful play on light and shadow will naturally attract more attention than the rest of the elements present on the screen. Therefore, even if only subconsciously, the viewer will instantly refocus and place the feature in question on the fovea, simultaneously creating certain hierarchical structure of film content (Solso 1994: 136). Consider for instance the following screenshot from the movie The Dark (2005, Fawcett) (figure 1. Full-colour illustration available in appendix, page XXX):

The window selectively illuminated against the background of a gloomy, dark house calls for the attention of the audience and allows them to make assumptions about what will happen next, and where. This non-verbal label therefore serves as a mental shortcut to realizing the directorial priorities and purposes - highlighting the important and obscuring the irrelevant helps the viewer focus on what the director wants to say and, as Geuens states, "ends up regulating our access to the field. It tells us where to look" (2000: 162).

The same mechanism for capturing an audience's focus can be observed with objects shot using backlight, which, according to Musburger and Kindem

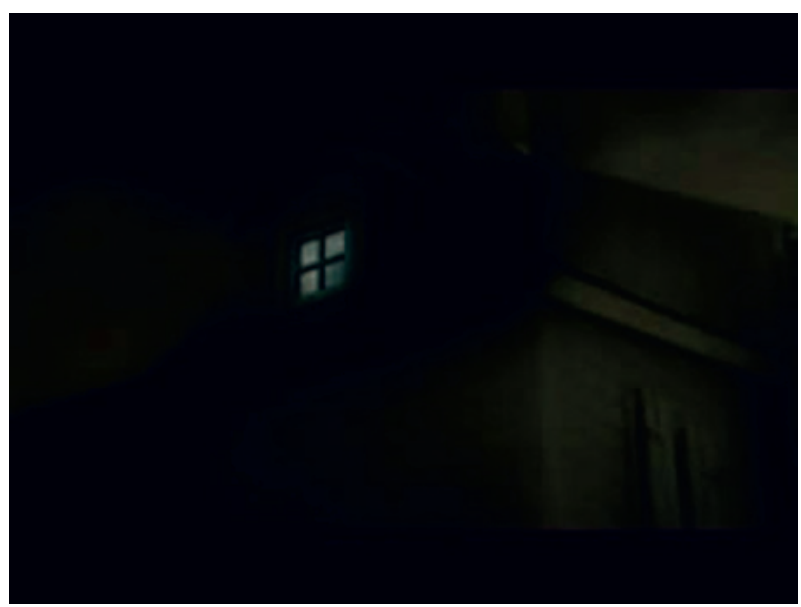

Figure 1: selectively highlighted objects as attention control in the viewer 
(2009: 243), also creates the additional effect of halo, separating physical shapes from the static background.

b) Scene punctuation marks, i.e. luminance patterns as film and scene writing tools with the potential to introduce new spatio-temporal circumstances (Ostaszewski 1999: 127)

- According to Arijon (2010: 540), lighting set-ups function as markers for the passing of time, symbolizing the end of one relevant cinematographic sentence and the beginning of another (e.g. by means of colors fading into black, white screen at the end of a given shot, etc.). At this point it is crucial to make a distinction between what Campbell calls 'snap-outs' and 'slow fades' (2004: 83). While the former is used to support the fast pace of the action and provide the viewers "with an after-image impressed on their retinas", the latter is considered

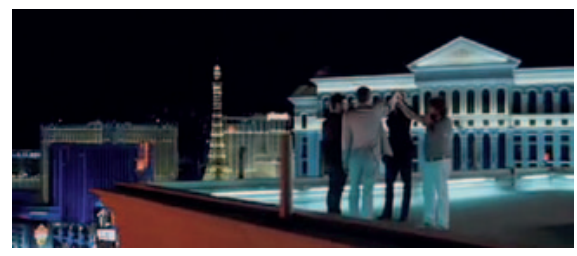

Figure 2

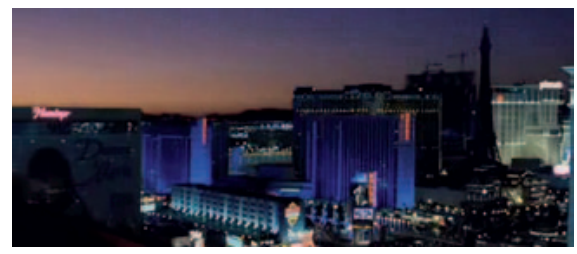

Figure 4

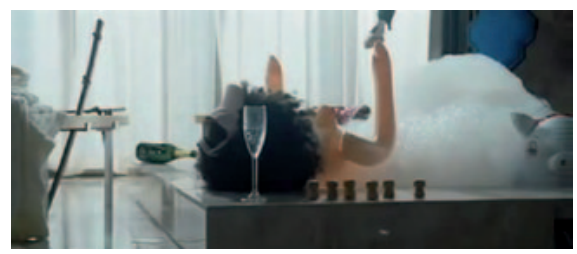

Figure 6

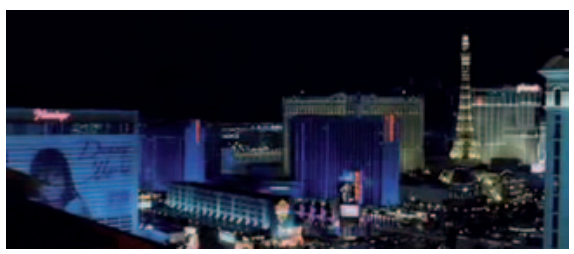

Figure 3

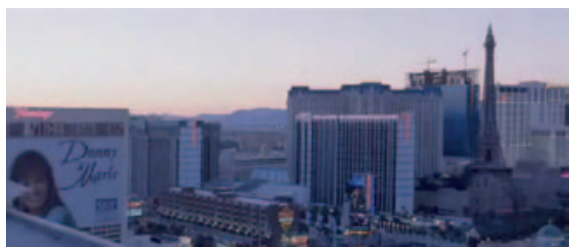

Figure 5

Figures 2-6: Images showing the use of light as a scene punctuation mark 
to allow the audience the necessary time to deal with the emotions triggered by the relevant image and let the experience sink in to their consciousness. Recall, for instance, the scene from The Hangover (2009, Phillips), where the characters wake up in the morning and find themselves totally perplexed. The leap between the previous scene, which is shot on the roof of the hotel at night, and the second, which is presented in plain morning light (see figures 2 and 6), could therefore be seen as a cinematographic full stop. The changing of the scenes, shot in fast lane with the city lights rapidly merging from dusk into dawn and the screen finally fading into white further supports the notion of a crazy night life and subsequent mental blackout which the characters are known to have experienced (see figures 3 to 5):

c) Story-telling tools

- Following the assertion made by Rockett (1988: 100), careful choice of appropriate lighting set-ups can contribute to, and indeed intensify, the general viewing experience and thus create an additional, nonverbal story line (e.g. using a gradual shift of the characters from the shadows into the light as a means of revealing them becoming clever and independent). ${ }^{3}$ The visual representation of the mood of the setting and its expressiveness constitute an integral part of a film's reception and perception. These are widely known to help introduce the viewer to the fictional world with which he is being confronted, bridge the gap between the physically unreachable reality lived by the characters on the screen and its mental representation developed individually by the audience, and also conceive a background for what is going to happen next (Geuens 2000: 164). The implemented luminance solutions can therefore successfully act as a substitute for dialogue and present the viewer with the unique opportunity to make his own (albeit cognitively advanced) inferences about the plot's development, a critical issue in the field of audio description and subtitling for the deaf and hard of hearing. Consider for instance the following screenshots (figures 7 - 11) from Black Swan (2010, Aronofsky):

3. A concept embraced for instance in The milk of sorrow (2009, Llosa). See Oppenheimer (2010: 33). 


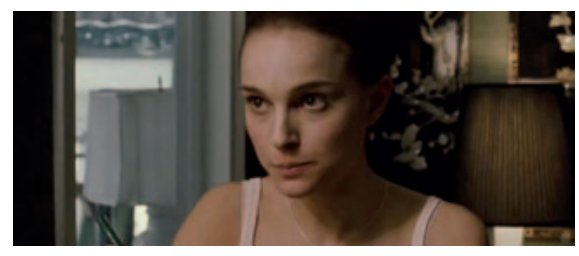

Figure 7

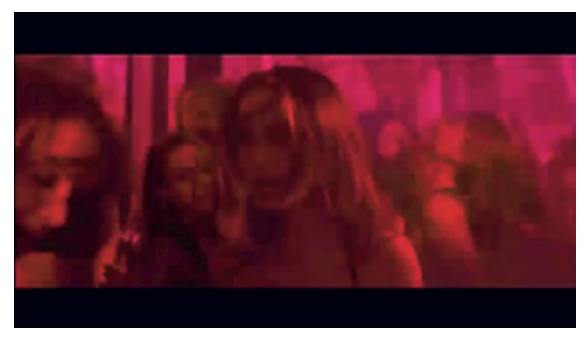

Figure 9

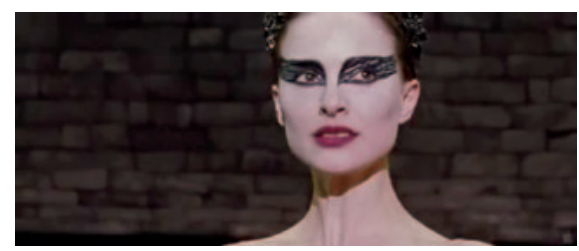

Figure 11

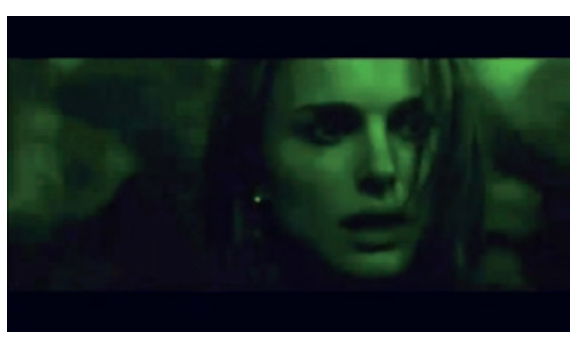

Figure 8

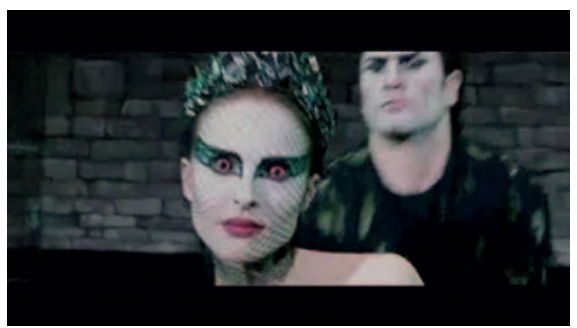

Figure 10

Figures 7-11: Images showing the use of light as a complementary story line

The sequence of these figures is not arbitrary. The images portray the gradual change of the main character, Nina, who from being a disturbed girl becomes a self-conscious, determined, albeit ultimately trapped woman. The luminance patterns employed support the story line and add to the narrative: Nina's room and the scenes when she is talking to her mother are shot using pale, grayish colors. Later in the movie, as she starts to gain confidence, she visits the disco, where the strobe lights symbolize the sharp contrast with her domestic life and mark the beginning of a tremendous change she is about to experience. The very last sequences of the movie, when Nina performs her dream ballet, are full of acute, cold lighting, which acts as a metaphor for cruel perfectionism and a deadly obsession with appearance. The play on 
light, contrast, and color saturation throughout the film thus corroborates the objective concept of Nina's dreadful transformation, at the same time fulfilling the role of the silent commentator of the cinematographic events (Sipos 2010: 140).

d) Tools triggering emotion and shaping perception

As previously claimed, the function of light in cinema extends far beyond mere pragmatics, i.e. making objects visible to the human eye. Furthermore, it is considered an active figurant in the cinematographic event, capable of establishing a harmonious interaction with the viewer's memory and his sense of aesthetics. Therefore, it serves as a vehicle for both knowledge and cognition: through combining light and shadow patterns, the director of photography can evoke certain emotional and mental states in the audience and thus position the relevant image within their personal experience and memory frames (Geuens 2000: 159). Naturally, there will be no two identical interpretations of the same visual input. Despite the objectively structured physical context in which it is being shown (i.e. color, shape, texture, etc.), every piece of art will be perceived from the perspective of the personal history and background of each viewer (Solso 1994: 101). According to Brown (1996: 12), the manifestation of these mechanisms ensues through:

- The cultural dimension of the implemented luminance pattern: i.e. an audience's ability to connote the inherent characteristics of lighting patterns employed with their emotional load and socially approved significance, e.g. dark = 'evil, unknown' vs. light = 'good, familiar'. These contrasting qualities have been widely used by horror movie makers: while night settings and characters shot in shadows create a tremendous sense of terror, foreboding, and lack of space, scenes lit with and objects positioned in daylight introduce a sensation of safety and strip the atmosphere of mystery (Rockett 1988: 100,102). Consider for instance these juxtaposing screenshots from The Lovely Bones (2009, Jackson):

The sharp contrast between the first three images (figures 12 to 14) and the last three (figures 15 to 17) allows the viewer to make clear assumptions about the disposition of the characters. Note for instance the difference in color and shadow distribution. Figures 12, 13 and 14 (i.e. those depicting Susie, the girl who falls victim to an atrocious murder) are radiant, vibrant, full of light and show blissful harmony. By contrast, figures 15, 16 and 17 (which 


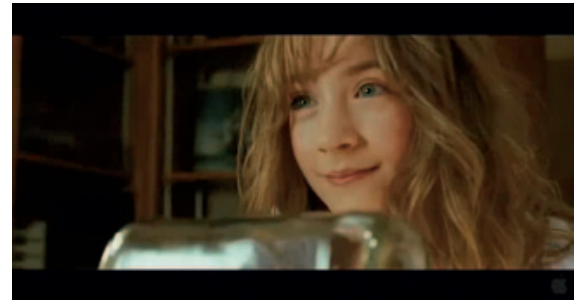

Figure 12

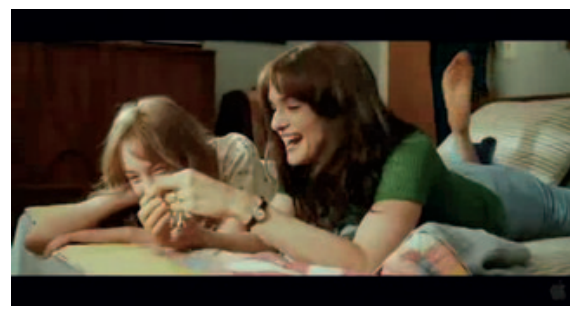

Figure 14

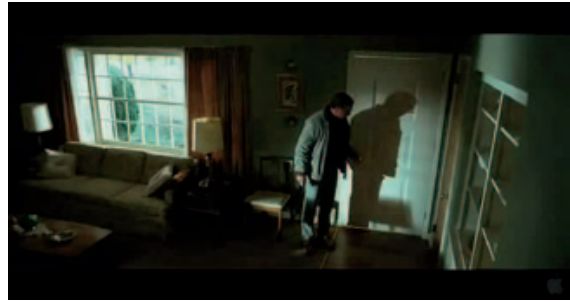

Figure 16

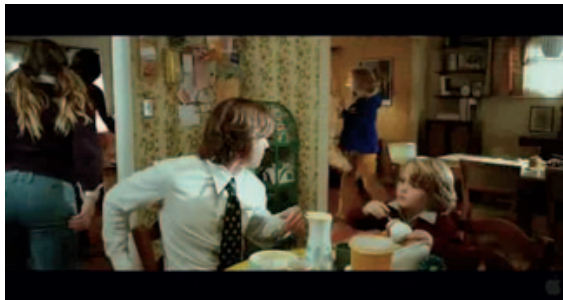

Figure 13

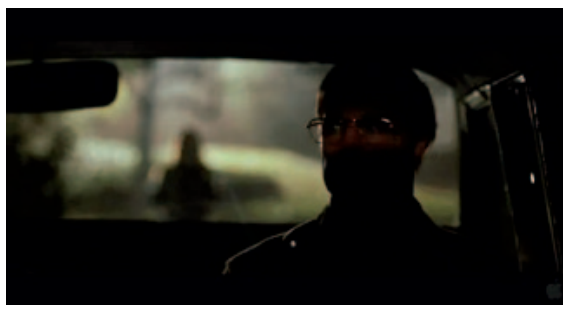

Figure 15

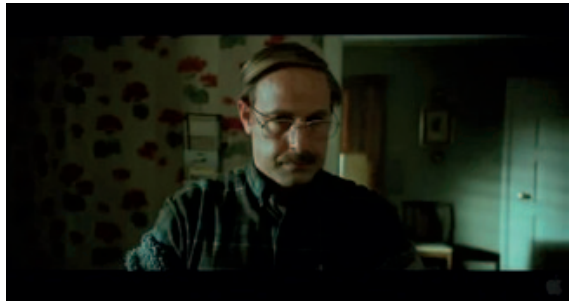

Figure 17

Figures 12-17: Images showing the different uses of light and shadow effects as the character's disposition is revealed

illustrate the murderer) make excessive use of shadows, dim light and grayish interiors. This observation also corresponds to the argument put forward by Dyer (1997: 61-64) who claims that it has already become a common practice to reserve bright colors (especially pale skin, blond hair and vivid settings) for good characters, and to present bad characters in twilight or cold dusk, and with obviously darker physical characteristics. ${ }^{4}$

4. With the exception of the concept of subverted canons: i.e. revealing new meaning by presenting a conventional form in an unconventional context (see Solso 1994: 244). 
Another way of communicating drama or mystery is the purposeful use of underlight and sidelight. Monaco (2009: 219) sees these techniques as successful vehicles for threat revelation, which, according to De Fez (2007: 146), work together with sharp contrasts, exaggerated characterization and rich décor, to make up the aesthetic whole of the cinematographic image.

- The psychological potential of lighting set-ups is supported by the viewer's ability to recognize the correlation between the employed color saturation and its metaphorical significance, e.g. red/orange $=$ 'hot, dreamy', blue/silver = 'cold, real'. The juxtaposition of acutely shot interiors and warm surfaces has been widely used by cinematographers to influence and shape the audience's perception of a given scene: following Malkiewicz's assertion (1986: 9), greens and blues

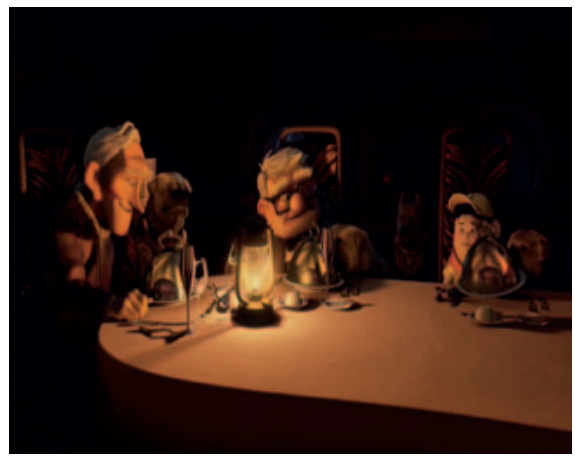

Figure 18

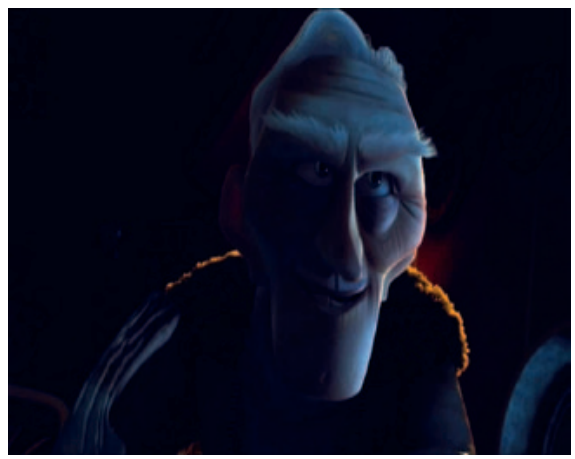

Figure 20

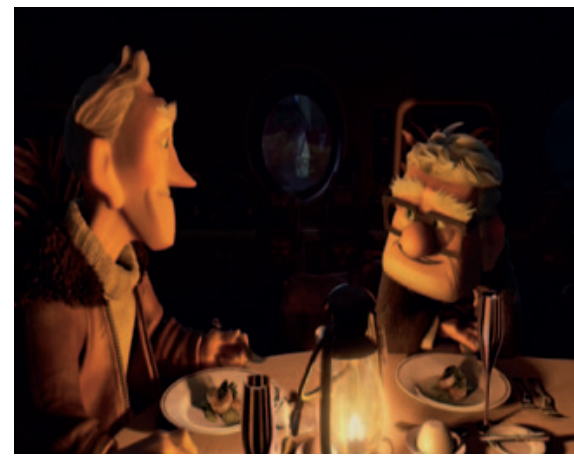

Figure 19

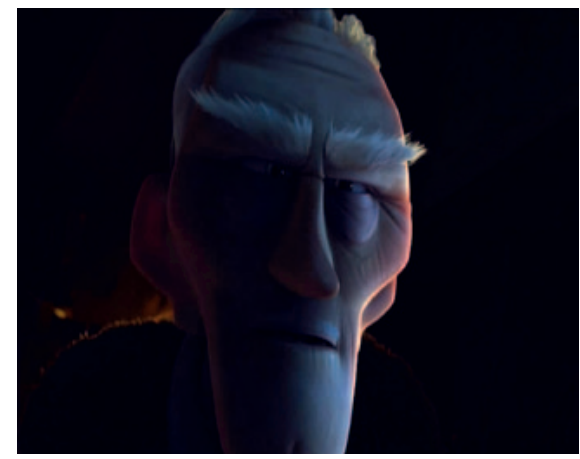

Figure 21

Figures 18-21: Images illustrating the use of light a tool to trigger a psychological response 
function in cinema as visual metaphors of night and twilight, whereas oranges, reds and yellows tend to heighten the emotional response of the viewer's nervous system and subsequently increase the spectator's heartbeat (a concept to be further investigated with respect to movies adaptations for the blind). Sharp cuts between such scenes make the viewers recognize the changes in the characters' disposition and help them adjust their attitude to the relevant plot development. Look at the screenshots from Pixar's Up (2009, Docter and Peterson) (figures 18 to 21$)$ :

Following the commentary provided by the director of cinematography on the supplementary DVD track, this abrupt change of color shades within the one scene was meant to complement the drama that was about to take place. The romantic, reddish ambient light used during the dinner is replaced by a wintery, piercing blue which reveals the real intentions of Muntz and his true, heartless character. The cozy illusion of a miraculous meeting with the childhood hero changes into a difficult and dangerous fight against the evil exploiter of wild-life, a concept evidently supported by sharper contrast and alternating color temperature.

Apart from the interpretation mentioned above, red and blue (depending on context), are also attributed (though not limited to) the following, juxtaposed characteristics (as outlined in Brill 2006: 174-175):

- predation vs. victimization;

- danger vs. resistance;

- alarm vs. safety;

However, the question of the incorporation of colors into the cinematographic image should be approached both cautiously and meticulously, for, as Bordwell and Thompson put it, "films can also use color to enhance the functions of their settings" (1990: 130). It is therefore critical for the cinematographer to carefully observe the relationships between light and the subconscious, and memorize them as a repetitive pattern and then use them appropriately when working on a scene with a similar feeling (Malkiewicz 1986: 1).

- Providers of kinetic energy, with their ability to add to the atmosphere of suspension of a given scene and to engender a general sensation of fear and curiosity in the audience (Sipos 2010: 170): it is a constant theme repeated in the literature surrounding visual perception that that which cannot be easily seen (i.e. the obscured) encourages and propels the imagination, thus at the same time contributing to the 
general viewing experience in the same way as the visible (Malkiewicz 1986: 2). Reduced control over what is occurring on the screen makes the lurking danger even more evident, which in turn directly translates into the emotional response of the viewer to the relevant image: irregular, sporadic, even piercing flashing lights cast against the background of deep night perfectly transmit the suspense, thus making the spectator anxious to see what will happen next. Recall one of the scenes from Irreversible (2002, Noé) (illustrated below in figures $22-26$ ), where the main character is obsessively looking for the rapist in a night club:

The prevailing darkness of the club is only lit by an orange bulb hanging loosely from the ceiling. The camera moves rapidly and carelessly, at times even turned upside down, and one can barely recognize the shapes encountered by the character on the way. The obscure and narrow hallways create the

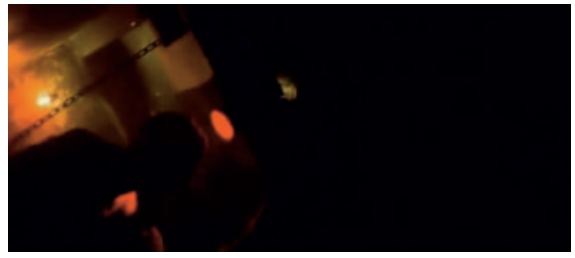

Figure 22

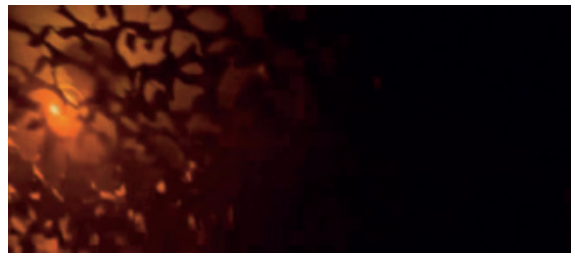

Figure 24

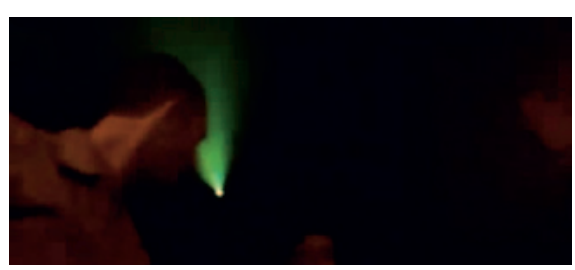

Figure 26

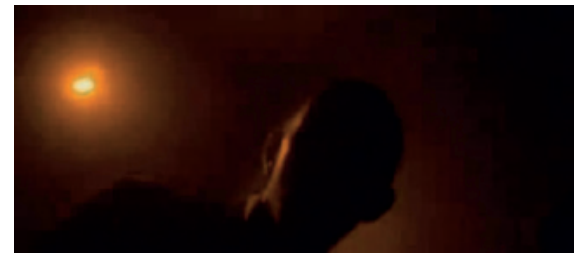

Figure 23

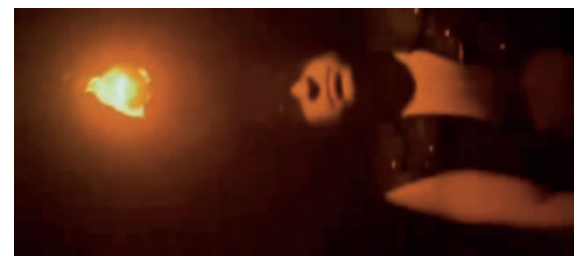

Figure 25

Figures 22-26: Images illustrating the use of flashing light as a provider of kinetic energy 
atmosphere of a dangerous and dubious underground. The aggressive, though infrequent light of the strobe also contributes to the experience of unease, of a hectic situation, and of emotional vertigo. One cannot be sure what will happen; the ambience of the scene could easily be characterized as accidental as everything is illuminated for only a split second. The image seems to be alive, with every flash of light revealing another piece of scarring reality. However, attempts to localize the source of the light are bound to fail: When will it shine again? From which perspective will it illuminate the characters? What will it reveal next time? And if it makes the interiors more visible, does the viewer really want to see the result? These are the questions the director of photography leaves largely unanswered, making the audience feel uneasy or uncertain as to the original intention of the image designer.

\section{Concluding remarks}

The meaning one extracts from any relevant piece of cinematographic art is the sum of myriad complementary planes individually interpreted by every viewer. Even though it may seem impossible to maintain the required highly advanced processing and perceptive activities at all existing levels of significance, it is claimed in the surrounding literature that broad visual literacy and extensive knowledge of filmic language guarantee better understanding of the film itself, and of its distinctive features. Focusing specifically on light and contrast patterns may indeed seem difficult, since both of these modalities correspond to the natural rhythm of day and night, and as such tend to be treated as cinematographically irrelevant. However, within the scope of the present article it has been shown that luminance patterns have the unique ability to create complementary realities as an additional storytelling tool to the scene itself, and so help support the viewing experience. They serve not only to direct the audience's attention, but also to create the mood of the filmic sequence, and thus evoke certain emotional responses which would all tie in with the initial idea of the director. The background created by lighting set-ups greatly contributes to the saturation of the audiences' imaginations, complementing and carrying on the plot, reflecting the characters' points of view and, at the same time, filling in the gaps between dialogues. Light has therefore been considered a meaningful and powerful language, which, even though operating without words, continues to speak to the mind of the viewer. Its functional scope has been slowly but surely to augment and reach out to the perceptual, psychological, and referential dimensions of the viewer. 


\section{Bibliography}

Anderson, Joseph D.; Barbara Fisher Anderson \& David Bordwell (eds.) (2005) Moving image theory. Ecological considerations. Carbondale: Southern Illinois University Press.

ARIJON, Daniel. (2010) Gramatyka języka filmowego. Translated by Feliks Forbert-Kaniewski. Warszawa: Wydawnictwo Wojciech Marzec.

BordWELL, David \& Kristin Thompson. (1990) Film art: an introduction. $3^{\text {rd }}$ ed. New York: McGraw-Hill Publishing Company.

BRILL, Lesley. (2006) Crowds, power, and transformation in cinema. Detroit, Michigan: Wayne State University Press.

BROWN, Blain. (1996) Motion picture and video lighting. Burlington, MA: Butterworth - Heinemann.

CAmpbell, Drew. (2004) Technical theatre for nontechnical people. New York: Allworth Press.

DE FEZ, Desirée. (2007) Películas clave del cine de terror moderno. Barcelona: Ediciones Robinbook.

DYER, Richard. (1997) White. London: Routledge.

Fellini, Federico \& Giovanni Grazzini (eds.) (1988) Comments on film. Translated by Joseph Henry. Fresno: California State University.

FIX, Ula \& Morgner Henrike. (2005) "Narration in Hörfilm - Theorie und Analyse". In: Fix, Ula (ed.) (2005) Hörfilm. Bildkompensation durch Sprache. Berlin: Erich Schmidt Verlag.

GeUENS, Jean-Pierre. (2000) Film production theory. Albany: State University of New York Press.

GutiérRez SAN Miguel, Begoña. (2002) "La luz como elemento expresivo de la narrativa audiovisual". Revista Comunicar 18: Descubrir los medios. p. 101.

MALKIEWICZ, Kris. (1986) Film lighting. Talks with Hollywood's cinematographers and gaffers. New York: Fireside.

MiLleRSON, Gerald. (1991) Lighting for Video. $3^{\text {rd }}$ ed. Oxford: Focal Press.

MitaL, Parag K.; Tim J. Smith; Robin L. Hill \& John M. Henderson. (2011) "Clustering of gaze during dynamic scene viewing is predicted by motion". Cognitive Computation 3:1. pp.5-24. Full-text version at: $<$ http://www.springerlink. $\mathrm{com} /$ content/u56646v1542m823t/fulltext.pdf >

MonaCO, James. (2009) How to read a film. Movies, media and beyond. $4^{\text {th }}$ ed. New York: Oxford University Press.

MUSBURGER, Robert B. \& Gorham Kindem. (2009) Introduction to media production. The path to digital media production. Oxford: Elsevier Inc.

NeLmES, Jill. (2003) An introduction to film studies. $3^{\text {rd }}$ ed. London: Routledge.

OPPENHEIMER, Jean. (2010) "An emotional transformation in Peru". American Cinematographer 91:9. p. 33. 
ORERO, Pilar. (2008) "Three different receptions of the same film". European Journal of English Studies 12:2. pp. 179-193.

Orero, Pilar. (2012) "Film Reading for Writing Audio Descriptions: A Word is Worth a Thousand Images?" In: Perego, Elisa (ed.) 2012. Emerging topics in translation: audio description. Trieste: ETU. pp. 13-28.

OSTASZEWSKI, Jacek. (1999) Film i poznanie: wprowadzenie do kognitywnej teorii filmu. Gdańsk: Wydawnictwo Uniwersytetu Jagiellońskiego.

Revault D’Allonnes, Fabrice. (2003) La luz en el cine. Madrid: Cátedra.

RocketT, Will H. (1988) Devouring whirlwind. Terror and transcendence in the cinema of cruelty. Connecticut: Greenwood Press, Inc.

SiPOS, Thomas M. (2010) Horror film aesthetics. Creating the visual language of fear. North Carolina: McFarland.

Solso, Robert L. (1994) Cognition and the Visual Arts. Cambridge, Massachusetts: MIT Press.

STAFFORD, Roy. (2007) Understanding audiences and the film industry. London: British Film Institute.

StURKen, Marita \& Lisa Cartwright. (2001) Practices of looking. An introduction into visual culture. New York: Oxford University Press.

\section{Filmography}

Antichrist. (2009) Lars von Trier. Denmark/Germany/France/Sweden/Italy/ Poland.

Black Swan. (2010) Darren Aronofsky. USA.

Equilibrium. (2002) Kurt Wimmer. USA.

Hangover. (2009) Todd Phillips. USA/Germany.

Irreversible. (2002) Gaspar Noé. France.

The dark. (2005) John Fawcett. Germany/UK.

The lovely bones. (2009) Peter Jackson. USA/UK/New Zealand.

Up. (2009) Pete Docter; Bob Peterson. USA. 


\section{BIONOTE / NOTA BIOGRÁFICA}

\section{Anna Maszerowska}

Anna Maszerowska holds a master's degree in Applied Linguistics from the Maria Curie-Skłodowska University of Lublin, Poland. Currently, she is a member of the CaiaC (Centre d'Accessibilitat i Intel-ligència Ambiental de Catalunya) research group at the Universitat Autonnoma de Barcelona, where she is conducting her doctoral research in the field of media accessibility. Her topic is on audio description and her main area of academic interest is on the incorporation of filmic language conventions, especially the ones of light and contrast patterns, into audio description scripts. She has worked as a freelance translator, subtitler and interpreter for various cultural events and companies.

Anna Maszerowska es licenciada en Lingüística Aplicada por la Universidad Maria Curie-Sklodowska de Lublin, Polonia. Actualmente es miembro del grupo de investigación CaiaC (Centre d'Accessibilitat i Intel-ligència Ambiental de Catalunya) de la Universitat Autònoma de Barcelona, donde está realizando su tesis doctoral en el campo de la accesibilidad en los medios de comunicación. Su materia de estudio es la audiodescripción. Su principal área de interés académico está en la incorporación de las convenciones del lenguaje cinematográfico, especialmente de los patrones de luz y contraste, en guiones de audiodescripción. Ha trabajado como traductora autónoma, realizando subtítulos y ha actuado como intérprete en varios eventos culturales y para varias empresas. 